\title{
Pengaruh Struktur Aset, Profitabilitas, Kebijakan Dividen, Pertumbuhan Perusahaan dan Ukuran Perusahaan Terhadap Kebijakan Hutang pada Perusahaan Perbankan yang Listing di BEI Tahun 2015-2018
}

Akuntansi Keuangan dan Pasar Modal

\author{
Ricky Yulianto Prabowo ${ }^{1)}$, Dien Noviany $\mathbf{R}^{2)}$, Abdulloh Mubarok ${ }^{3)}$ \\ Fakultas Ekonomi dan Bisnis, Universitas Pancasakti, Tegal \\ rickydewanto27@gmail.com,diennovi@yahoo.co.id, abdulloh_mubarok@upstegal.ac.id
}

\begin{abstract}
This study aims to in order to understand the the influence of the structure of assets, its satisfactory profitability as, dividend policy, growth of the company and the size of the company for policies in debt on banking company listing on BEI years 2015-2018. This research is research descriptive of with of a quantitative approach .A population that used in this research was the rest of the company on the banking listed in urban village BEI 42 company for the mortgage bankers association. The sample used in this research that is by using data collection techniques of sampling ( purposive ) consisting of 9 company. The research uses the data analysis used is linear regression analysis to the multiple SPSS 22 version. The research results show that structure assets not influence the policies the government debt, the significant 0,090 profitability influence the policies the government debt, the significant 0,004 dividends influence the policies the government policy the 0,002 , significant debt company growth influence the policies the government debt, the significant 0,000 size companies did not influence the policies the government the significant debt 0,074 . The determination of the the obtained $R^{2} 0,792$ or $79,2 \%$. Means that policy in the model $79,2 \%$ debt is affected by structure assets, profitability, dividends, policy growth firm and company size.The remaining fund $20,8 \%$ affected by other factors out model this study.
\end{abstract}

Keywords : structure, assets, profitability, dividend policy, firm growth and firm size, debt policy. 


\begin{abstract}
ABSTRAK
Penelitian ini bertujuan untuk mengetahui pengaruh struktur aset, profitabilitas, kebijakan dividen, pertumbuhan perusahaan dan ukuran perusahaan terhadap kebijakan hutang pada perusahaan perbankan yang listing di BEI tahun 2015-2018. Penelitian ini adalah penelitian deskriptif dengan pendekatan kuantitatif. Populasi yang digunakan dalam penelitian ini adalah seluruh perusahaan perbankan yang terdaftar pada BEI yang berjumlah 42 perusahaan. Sampel yang digunakan dalam penelitian ini yaitu dengan menggunakan Teknik Pengumpulan Data (Purposive Sampling) yang terdiri dari 9 perusahaan. Penelitian ini menggunakan metode analisis data yang digunakan adalah analisis regresi linier berganda dengan program SPSS Versi 22. Hasil penelitian menunjukkan bahwa struktur aset tidak berpengaruh terhadap kebijakan hutang dengan nilai signifikan 0,090, profitabilitas berpengaruh terhadap kebijakan hutang dengan nilai signifikan 0,004, kebijakan dividen berpengaruh terhadap kebijakan hutang dengan nilai signifikan 0,002 , pertumbuhan perusahaan berpengaruh terhadap kebijakan hutang dengan nilai signifikan 0,000, ukuran perusahaan tidak berpengaruh terhadap kebijakan hutang dengan nilai signifikan 0,074. Hasil uji koefisien determinasi diperoleh $\mathrm{R}^{2}$ sebesar 0,792 atau 79,2\%. Dapat diartikan bahwa 79,2\% kebijakan hutang dalam model ini dipengaruhi oleh struktur aset, profitabilitas, kebijakan dividen, pertumbuhan perusahaan dan ukuran perusahaan. Sedangkan sisanya sebesar 20,8\% dipengaruhi oleh faktor lain diluar model penelitian ini.
\end{abstract}

Kata kunci: Struktur Aset, Profitabilitas, Kebijakan Dividen, Pertumbuhan Perusahaan, Ukuran Perusahaan, Kebijakan Hutang.

\title{
1. Pendahuluan
}

1.1 Latar Belakang

Persaingan pasar ekonomi global tentu tak lepas dari adanya perkembangan zaman, perkembangan teknologi, dan perkembangan dalam dunia bisnis. Hal ini menuntut perusahaan untuk melakukan pengembangan dalam usahanya agar mampu menghadapi persaingan yang semakin ketat (Mulyati, 2016). Suatu perusahaan didirikan dengan berbagai tujuan. Salah satu tujuan utama dari perusahaan adalah untuk memaksimalkan kemakmuran dan keuntungan bagi para pemegang sahamnya (Brigham dan Houston, 2006 dalam Hidayat, 2013).

Pemegang saham tidak dapat mengatasi semua keputusan dan aktivitas yang dilakukan oleh manajer. Manajer seringkali mempunyai tujuan lain dengan tujuan utama perusahaan, sehingga akan timbul konflik kepentingan antara manajer dengan pemegang saham atau yang biasa disebut dengan konflik keagenan. Meminimumkan konflik kepentingan antara manajer dengan pemegang saham bisa menggunakan mekanisme 
pengawasan yang dapat mensejajarkan kepentingan-kepentingan yang terkait tersebut (Manan, 2004 dalam Susilawati et.al, 2012). Namun dengan munculnya mekanisme pengawasan tersebut akan menimbulkan biaya yang disebut dengan agency cost (Wahidahwati, 2002 dalam Syadeli, 2013).

Ada beberapa alternatif untuk mengurangi agency cost yaitu dengan meningkatkan kepemilikan saham perusahaan oleh manajemen, mekanisme pengawasan dalam perusahaan, meningkatkan dividen payout ratio dan yang terakhir meningkatkan pendanaan dengan hutang. Peningkatan hutang akan menurunkan agency problem dan menurunkan excess cash flow yang ada dalam perusahaan sehingga dapat menurunkan kemungkinan pemborosan yang dilakukan oleh manajemen (Wahidahwati, 2002 dalam Indahningrum dan Handayani, 2009)..

Secara empiris penelitian mengenai faktor-faktor yang mempengaruhi kebijakan hutang perusahaan telah sering dilakukan antara lain oleh Hendria (2015), Steven dan Lina (2011), Astuti (2014), Indahningrum dan Handayani (2009), Sheisarvian et.al (2015), Susilawati et.al (2012), Djabid (2009), Karinaputri dan Sofian (2012), Mulyati (2016) namun hasil penelitian tersebut masih mendapatkan temuan yang tidak konsisten antar satu peneliti dengan peneliti yang lain sehingga perlu dilakukan pengujian lebih lanjut untuk mengetahui konsistensi temuan jika diterapkan pada obyek yang berbeda.

\subsection{Kajian Pustaka}

Agency Theory

Teori Keagenan (agency theory) merupakan teori yang berusaha untuk menerangkan tindakan atau aksi dari pihak-pihak yang terlibat adanya hubungan kontrak khususnya yang dilakukan oleh pihak perusahaan atau manajemen (Kiswara, 1999: 5 dan Kelly, 1983: 183 dalam Kholmi, 2010).

\section{Trade-Off Theory}

Teori trade-off adalah teori yang menyatakan bahwa hubungan antara struktur modal dengan nilai perusahaan terdapat suatu tingkat leverage yang optimal (Harjito, 2011). Menurut teori ini struktur modal yang optimal dicapai, apabila nilai sekarang dari tax shield hutang adalah sama dengan nilai sekarang dari biaya kesulitan keuangan hutang. 


\section{Pecking Order Theory}

Pecking Order Theory adalah teori menyatakan bahwa perusahaan melakukan keputusan pendanaan secara hierarki dari pendanaan internal ke eksternal. Urutan pendanaan mulai dari dana yang bersumber dari laba ditahan, kemudian hutang dan akhirnya sampai pada penerbitan ekuitas baru, artinya dimulai dari sumber dana dengan biaya termurah (Myers dan Majluf, 1984 dalam Harjito, 2011).

\section{Kebijakan Hutang}

Kebijakan hutang merupakan salah satu penentu arah pertimbangan dari struktur modal, karena struktur modal perusahaan merupakan perimbangan dari jumlah hutang jangka pendek (permanen), hutang jangka panjang, saham preferen, dan juga saham biasa (Sheisarvian et.al, 2015).

\section{Struktur Aset}

Struktur aset adalah kekayaan atau sumber-sumber ekonomi yang dimiliki oleh perusahaan yang diharapkan akan memberi manfaat dimasa yang akan datang (Kesuma, 2009 dalam Hidayat, 2013).

\section{Profitabilitas}

Profitabilitas merupakan kemampuan suatu perusahaan untuk mendapatkan laba ( keuntungan ) dalam suatu periode tertentu (Hery, 2017:7). perusahaan dengan tingkat pengembalian yang tinggi atas investasi menggunakan hutang yang relatif kecil karena tingkat pengembalian yang tinggi memungkinkan perusahaan untuk membiayai sebagian besar pendanaan internal (Susilawati et.al, 2012).

\section{Kebijakan Dividen}

Kebijakan dividen adalah keputusan apakah laba yang diperoleh perusahaan akan dibagikan kepada pemegang saham sebagai dividen atau akan ditahan dalam bentuk laba ditahan guna pembiayaan investasi di masa yang akan datang (Musthafa, 2017:141).

\section{Pertumbuhan Perusahaan}

Pertumbuhan dinyatakan sebagai pertumbuhan total aset dimana pertumbuhan aset masa lalu akan menggambarkan profitabilitas yang akan datang dan pertumbuhan yang 
akan datang (Taswan, 2003 dalam Dhani dan Utama, 2017). Sedangkan Pertumbuhan aset dihitung sebagai persentase perubahan aset pada saat tertentu terhadap tahun sebelumnya (Saidi, 2004 dalam Nadillah, 2017).

\section{Ukuran Perusahaan}

Ukuran perusahaan adalah suatu skala di mana dapat diklasifikasikan besar kecilnya perusahaan menurut berbagai cara antara lain dengan total aset, nilai pasar saham, dan lainlain Prasetyorini (dalam Hery, 2017:13). Skala yang dapat diklasifikasikan dalam besar kecilnya perusahaan ada berbagai cara antara lain dengan total aset, log size.

\subsection{Kerangka Pemikiran}

\section{Pengaruh Struktur Aset terhadap Kebijakan Hutang}

Struktur aset adalah penentu berapa besar alokasi untuk masing-masing komponen aset, baik dalam aset lancar maupun dalam aset tetap (Susilawati et.al, 2012). Besarnya aset tetap suatu perusahaan dapat menentukan besarnya penggunaan hutang. Perusahaan yang memiliki aset tetap dalam jumlah besar dapat menggunakan hutang dalam jumlah besar karena aset tersebut dapat digunakan sebagai jaminan pinjaman (Mamduh, 2004 dalam Sujarweni et.al, 2014). Hal ini didukung oleh Susilawait et.al (2012), Steven dan Lina (2013) dan Sujarweni et.al (2014).

H1 : Struktur Aset berpengaruh terhadap Kebijakan Hutang

\section{Pengaruh Profitabilitas terhadap Kebijakan Hutang}

Perusahaan dengan tingkat profitabilitas yang tinggi akan cenderung menggunakan hutang yang sedikit. Hal ini disebabkan karena perusahaan akan lebih memilih pendanaan untuk operasional nya menggunakan dana internal perusahaan dengan asumsi bahwa perusahaan akan mengalokasikan sebagian besar keuntungan pada laba ditahan (Narita, 2012). Pada tingkat profitabilitas rendah tentunya kebutuhan dana perusahaan belum mencukupi, maka dari itu perusahaan dapat menggunakan hutang Hal ini didukung hasil penelitian yang dilakukan Karinaputri dan Sofian (2012), Syadeli (2013) dan Narita (2012).

H2 : Profitabilitas berpengaruh terhadap Kebijakan Hutang

\section{Pengaruh Kebijakan Dividen terhadap Kebijakan Hutang}


Peningkatkan jumlah hutang yang digunakan juga dipengaruhi oleh pembagian deviden. Semakin besar jumlah dividen yang dibagikan maka akan meningkatkan penggunaan hutang. Semaik tinggi dividen yang dibagikan maka akan mengurangi arus kas perusahaan sehingga dalam memenuhi kebutuhan operasionalnya perusahaan akan mencari sumber dana alternatif yang relevan misalnya dengan hutang. Hal ini juga diteliti Hidayat (2013), Steven dan Lina (2011)

H3 : Kebijakan Dividen berpengaruh terhadap Kebijakan Hutang

\section{Pengaruh Pertumbuhan Perusahaan terhadap Kebijakan Hutang}

Perusahaan yang memiliki tingkat pertumbuhan yang tinggi akan membutuhkan pendanaan yang cukup besar. Hal ini dikarenakan tingkat pertumbuhan yang tinggi mengindikasikan perusahaan untuk melakukan ekspansi sehingga membutuhkan pendanaan yang cukup besar (Steven dan Lina 2011). Kenyataan seperti ini membuat perusahaan dihadapkan dengan pilihan sumber pendanaan yang lebih murah. Dalam hal ini penerbitan surat hutang lebih disukai perusahaan dibandingkan dengan mengeluarkan surat saham baru karena biaya emisi saham baru lebih besar dibandingkan dengan biaya hutang (Indahningrum dan Handayani, 2009). Penelitian ini didukung juga jurnal Karinaputri dan Sofian (2012).

H4 : Pertumbuhan Perusahaan berpengaruh terhadap Kebijakan Hutang

\section{Pengaruh Ukuran Perusahaan terhadap Kebijakan Hutang}

Perusahaan yang besar memiliki aset yang cukup besar yang nantinya dapat dipergunakan sebagai jaminan untuk melakukan hutang (Nuraina, 2012). Perusahaan besar dapat dengan mudah mengakses pasar modal. Kemudahan untuk mengakses pasar modal berarti perusahaan memiliki fleksibilitas dan kemampuan untuk mendapat dana lebih banyak ( Manan, 2004 dalam Susilawati et.al, 2012). Hal ini didukung oleh penelitian Hendria (2015) dan Syadeli (2013).

H5 : Ukuran Perusahaan berpengaruh terhadap Kebijakan Hutang

\subsection{Metode Penelitian}

Dalam pelaksanaan penelitian ini dilakukan menggunakan metode deskriptif kuantitatif. Sampel penelitian ini adalah perusahaan perbankan yang terdaftar di Bursa Efek 
Indonesia tahun 2015-2018. Populasi berjumlah sebanyak 42 Perusahaan. Teknik pengambilan sampel dalam penelitian ini adalah dengan metode Purpose Sampling. Kriteria pengambilan sampel dalam enelitian ini yaitu Perusahaan perbankan yang terdaftar di BEI sampai dengan tahun 2018, Perusahaan memiliki kelengkapan data DPR (deviden payout ratio) selama tahun pengamatan.

Berdasarkan kriteria yang sudah ditentukan hanya ada 9 perusahaan yang mmenuhi kriteria pemilihan sampel dengan periode pengamatan 4 tahun, sehingga total pengamatan sebanyak 36.

\subsection{Operasional Variabel}

\section{Kebijakan Hutang}

Kebijakan hutang dilambangkan dengan debt to equity ratio. Rasio ini menunjukkan hubungan antara jumlah pinjaman jangka panjang yang diberikan oleh kreditur denga jumlah modal sendiri yang diberikan oleh pemilik perusahaan. Secara matematis kebijakan hutang diformulasikan sebagai berikut (Susilawati et.al, 2012) :

$D E R=\frac{\text { Total Debt }-D P K}{\text { Total Equity }}$

\section{Struktur Aset}

Struktur aset dapat iukur dengan menggunakan hasil bagi antara aset tetap terhadap total aset seperti yang digunakan oleh Hidayat (2013) :

STA $=\frac{\text { Aset Tetap }}{\text { Total Aset }}$

\section{Profitabilitas}

Variabel ini diukur dengan skala rasio, yakni Return on Aset yang dinyatakan dalam rasio laba operasi dengan penjualan bersih pada laporan laba rugi saat akhir tahun. Rumus dari profitabilitas menurut Lukman Syamsudin (2011) dalam Sheisarvian et.al (2015) :

$R O A=\frac{\text { Laba Operasi }}{\text { Total aset }}$

Kebijakan Dividen 
Kebijakan dividen dilambangkan dengan dividen payout ratio (DPR), yang merupakan perbandingan antara besarnya deviden kas yang dibagikan terhadap earning after tax (Ismiyati dan Hanafi, 2003 dalam Sheisarvian et al, 2015) :

$D P R=\frac{\text { Deviden }}{\text { Earning after tax }}$

\section{Pertumbuhan Perusahaan}

Pertumbuhan perusahaan diukur dari perubahan total asset. Secara matematis pertumbuhan perusahaan dapat diformulasikan sebagai berikut sesuai dengan penelitian yang dilakukan oleh (Dhani dan Utama, 2017) :

Growth $=\frac{\text { Total aset } t-\text { total aset } t-1}{\text { Total aset } t-1}$

\section{Ukuran Perusahaan}

Ukuran perusahaan merupakan rasio lagaritma natural dari total aset sebagai dasar pengukuran (Soesetio, 2008 dalam Hendria, 2015) :

Ln Total Aset

\section{Hasil dan Pembahasan}

Berdasarkan hasil data yang dikumpulkan dengan metode pengumpulan data peroleh deskripsi data tentang variabel penelitian seperti pada tabel berikut :

\subsection{Statistik Deskriptif}

Tabel 1

Uji Statistik Deskriptif

\begin{tabular}{|l|r|r|r|r|r|}
\hline & $\mathrm{N}$ & Minimum & Maximum & \multicolumn{1}{c|}{ Mean } & \multicolumn{1}{c|}{ Std. Deviation } \\
\hline STA & 36 &, 0091 &, 1121 &, 036917 &, 0316050 \\
ROA & 36 &, 0111 &, 0363 &, 022847 &, 0070490 \\
DPR & 36 &, 0754 &, 4545 &, 257025 &, 1002408 \\
GROWTH & 36 &,- 0743 &, 4348 &, 132472 &, 1177620 \\
SIZE & 36 & 12,8173 & 15,1129 & 14,136161 &, 8212782 \\
DER & 36 &, 0974 & 1,1311 &, 576658 &, 3366578 \\
Valid N (listwise) & 36 & & & & \\
\hline
\end{tabular}

Sumber : Data diolah dengan SPSS versi 22 (2019) 


\subsection{Uji Normalitas}

Tabel 2

Hasil Uji Normalitas

One-Sample Kolmogorov-Smirnov Test

\begin{tabular}{|ll|r|}
\hline & & $\begin{array}{c}\text { Unstandardized } \\
\text { Residual }\end{array}$ \\
\hline Normal Parameters & Mean & 36 \\
& Std. Deviation &, 0000000 \\
Most Extreme Differences & Absolute &, 19633432 \\
& Positive &, 084 \\
& Negative &, 065 \\
Test Statistic & &,- 084 \\
Asymp. Sig. (2-tailed) & &, 084 \\
\hline
\end{tabular}

Sumber : Data diolah dengan SPSS versi 22 (2019)

Berdasarkan nilai Test Statistic Kolmogrov-Smirnov adalah 0,084 dan signifikan 0,200 yang nilainya lebih besar daripada 0,05. Hal ini menunjukkan bahwa distribusi data dalam penelitian ini normal.

4.3 Uji Multikolinieritas

Tabel 3

Hasil Uji Multikolinieritas

\begin{tabular}{|ll|r|r|}
\hline \multirow{2}{*}{\multicolumn{2}{|c|}{ Model }} & \multicolumn{2}{|c|}{ Collinearity Statistics } \\
\cline { 3 - 4 } & \multicolumn{1}{|c|}{ Tolerance } & \multicolumn{1}{c|}{ VIF } \\
\hline 1 & (Constant) & & \\
& STA &, 554 & 1,804 \\
& ROA &, 272 & 3,673 \\
& DPR &, 599 & 1,668 \\
GROWTH &, 609 & 1,643 \\
& SIZE &, 244 & 4,096 \\
\hline
\end{tabular}




\begin{tabular}{|c|c|c|c|}
\hline \multicolumn{4}{|c|}{ Coefficients $^{a}$} \\
\hline \multirow{2}{*}{\multicolumn{2}{|c|}{ Model }} & \multicolumn{2}{|c|}{ Collinearity Statistics } \\
\hline & & Tolerance & VIF \\
\hline \multirow[t]{6}{*}{1} & (Constant) & & \\
\hline & STA &, 554 & 1,804 \\
\hline & ROA & ,272 & 3,673 \\
\hline & DPR &, 599 & 1,668 \\
\hline & GROWTH & 609 & 1,643 \\
\hline & SIZE & ,244 & 4,096 \\
\hline
\end{tabular}

Sumber: Data diolah dengan SPSS versi 22 (2018)

Berdasarkan tabel diatas, diketahui bahwa seluruh variabel independen memiliki nilai tolerance lebih besar dari 0,1 dan VIF seluruh variabel kurang dari 10 sehingga dapat disimpulkan bahwa variabel independen struktur aset, profitabilitas, kebijakan dividen, pertumbuhan perusahaan dan ukuran perusahaan tidak mempunyai masalah dengan multikolinieritas.

\subsection{Uji Heteroskedastisitas}

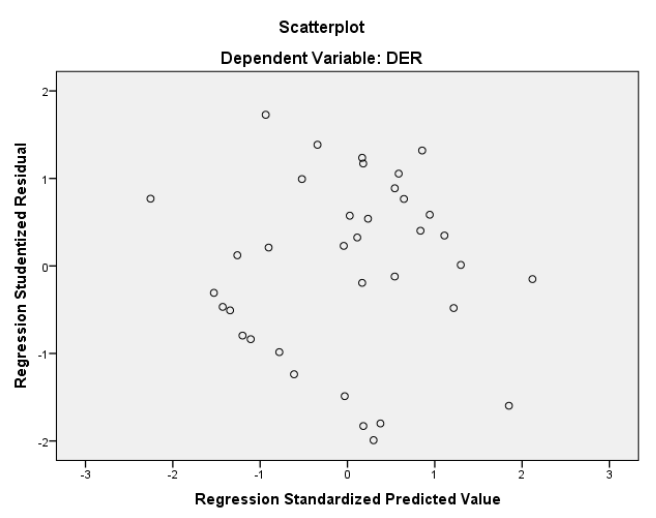

Gambar 2

Hasil Uji Heteroskedastisitas

Berdasarkan grafik scatterplot menunjukkan bahwa tidak ditemukan pola tertentu yang teratur dan titik-titik menyebar di atas dan di bawah angka 0 pada sumbu Y. Hal ini berarti tidak terjadi heteroskedastisitas pada model regresi 


\subsection{Uji Autokorelasi}

Tabel 4

Hasil Uji Autokorelasi

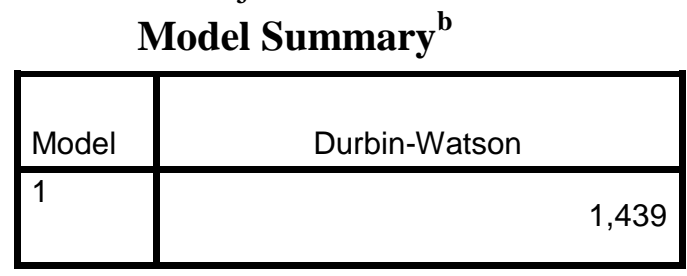

Berdasarkan data tabel 4.4 diperoleh nilai hitung Durbin-Watson sebesar 1,439, hal ini menunjukkan bahwa nilai tersebut lebih besar dari -2 dan lebih kecil dari 2 atau $-2<1,260<2$. Maka dapat disimpulkan, data yang digunakan dalam penelitian ini bebas auokorelasi atau tidak terjadi autokorelasi.

\subsection{Analisis Regresi Linier Berganda}

Tabel 5

Hasil Analisis Regresi Linier Berganda

Coefficients $^{\mathrm{a}}$

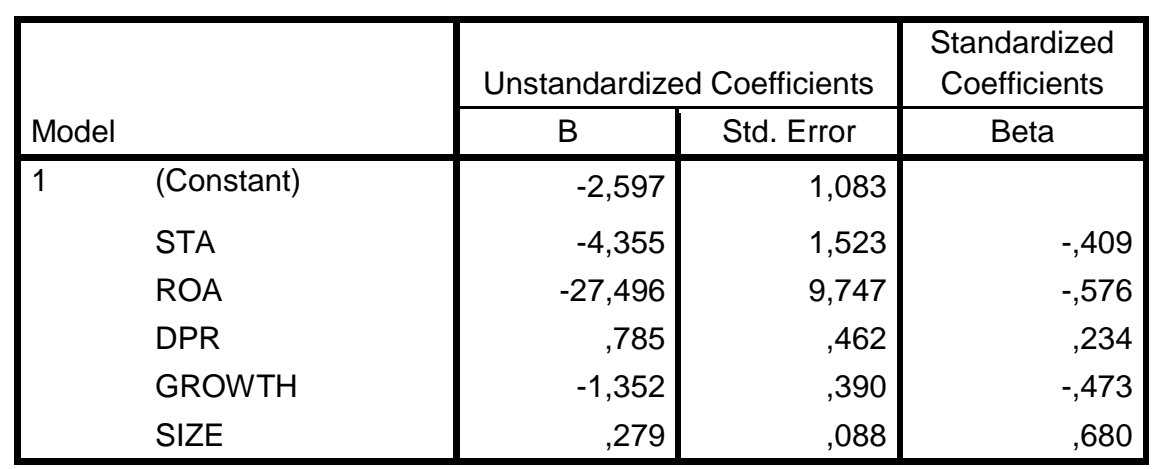

Berdasarkan hasil analisis regresi linier berganda diperoleh persamaan regresi yaitu $\hat{Y}=-2,597+(-4,355) X_{1}+(-27,496) X_{2}+(0,785) X_{3}+(-1,352) X_{4}+(0,279) X_{5}$. Dari persaman regresi yang diperoleh tersebut dapat diartikan sebagai berikut:

a) Konstanta sebesar -2,597 satuan; artinya jika struktur aset (X1), profitabilitas (X2), kebijakan dividen (X3), pertumbuhan perusahaan(X4) dan ukuran perusahaan (X5) nilainya adalah 0, maka Kebijakan Hutang (Y) nilainya adalah 2,597 satuan.

b) Koefisiensi regresi variabel struktur aset $\left(X_{1}\right)$ sebesar $-4,355$ satuan; artinya jika variabel independen lain nilainya tetap dan struktur aset mengalami kenaikan 1 satuan maka kebijakan hutang (Y) akan mengalami kenaikan sebesar -4,355 satuan. 
c) Koefisiensi regresi variabel profitabilitas $\left(\mathrm{X}_{2}\right)$ sebesar -27,496 satuan; artinya jika variabel independen lain nilainya tetap dan profitabilitas mengalami kenaikan 1 satuan, maka kebijakan hutang (Y) akan mengalami kenaikan sebesar -27,496 satuan.

d) Koefisiensi regresi variabel kebijakan dividen $\left(\mathrm{X}_{3}\right)$ sebesar 0,785 satuan; artinya jika variabel independen lain nilainya tetap dan kebijakan dividen mengalami kenaikan 1 satuan, maka kebijakan hutang (Y) akan mengalami kenaikan sebesar 3,402 satuan.

e) Koefisiensi regresi variabel pertumbuhan perusahaan $\left(X_{4}\right)$ sebesar -1,352 satuan; artinya jika variabel independen lain nilainya tetap dan pertumbuhan perusahaan mengalami kenaikan 1 satuan, maka kebijakan hutang (Y) akan mengalami kenaikan sebesar $-1,352$ satuan.

f) Koefisiensi regresi variabel ukuran perusahaan $\left(\mathrm{X}_{5}\right)$ sebesar 0,279 satuan; artinya jika variabel independen lain nilainya tetap ukuran perusahaan mengalami kenaikan 1 satuan, maka kebijakan hutang (Y) akan mengalami kenaikan sebesar 0,279 satuan.

\subsection{Uji Statistik F}

Tabel 6

Hasil Uji Statistik F

\begin{tabular}{|l|r|r|r|r|}
\hline Model & Sum of Squares & df & F & Sig. \\
\hline 1 Regression & 2,618 & 5 & 11,642 &, $000^{\circ}$ \\
Residual & 1,349 & 30 & & \\
Total & 3,967 & 35 & & \\
\hline
\end{tabular}

a. Dependent Variable: DER

b. Predictors: (Constant), SIZE, STA, GROWRTH, DPR, ROA

Dari data penghitungan uji Signifikansi yang tampak pada tabel di atas, nilai F hitung sebesar 11,642 dengan nilai signifikansi sebesar 0,000 $<0,05$. Sehingga struktur aset, profitabilitas, kebijakan dividen, pertumbuhan perusahaan dan ukuran perusahaan mempunyai pengaruh yang signifikan terhadap kebijakan hutang. 


\subsection{Uji Statistik $T$}

Tabel 7

Hasil Uji Statistik $\mathrm{t}$

Coefficients $^{\mathrm{a}}$

\begin{tabular}{|c|c|c|c|c|c|}
\hline \multirow[b]{2}{*}{ Model } & \multicolumn{2}{|c|}{$\begin{array}{c}\text { Unstandardized } \\
\text { Coefficients }\end{array}$} & \multirow{2}{*}{$\begin{array}{c}\begin{array}{c}\text { Standardized } \\
\text { Coefficients }\end{array} \\
\text { Beta }\end{array}$} & \multirow[b]{2}{*}{$\mathrm{T}$} & \multirow[b]{2}{*}{ Sig. } \\
\hline & $B$ & Std. Error & & & \\
\hline (Constant) & $-2,597$ & 1,083 & & $-2,398$ & ,023 \\
\hline STA & $-4,355$ & 1,523 &,- 409 & $-2,859$ & ,008 \\
\hline $\mathrm{ROA}$ & $-27,496$ & 9,747 &,- 576 & $-2,821$ & ,008 \\
\hline DPR & 785, & 462, & 234, & 1,699 & 100, \\
\hline GROWTH & $-1,352$ & ,390 &,- 473 & $-3,464$ & ,002 \\
\hline SIZE & 279, & 088, & 680, & 3,156 & 004, \\
\hline
\end{tabular}

Dependent Variable: DER

Berdasarkan tabel tersebut dapat diketahui bahwa:

a. Struktur aset menghasilkan tingkat signifikan 0,008 yang artinya tingkat signifikansi variabel struktur aset dengan nilai $0,008<0,05$, maka dapat disimpulkan bahwa struktur aset berpengaruh terhadap kebijakan hutang yang artinya $\mathrm{H}_{1}$ diterima. Hal ini terkait dengan kecendrungan bahwa manajemen akan berhati-hati dalam menggunakan dan membuat kebijakan hutang baru, sehingga hutang perusahaan akan semakin kecil. Semakin tinggi struktur aset (semakin besar jumlah aset tetap) maka penggunaan modal sendiri akan semakin tinggi, dan penggunaan modal asing akan semakin sedikit.

Hasil penelitian ini sejalan dengan penelitian yang dilakukan Rivandi dan Mega (2018) yang menunjukkan hasil bahwa struktur aset berpengaruh terhadap kebijakan hutang. Hasil yang berbeda ditunjukkan pada hasil penelitian yang dilakukan oleh Mulyati (2016) yang menunjukkan bahwa struktur aset tidak berpengaruh terhadap kebijakan hutang, karena apabila perusahaan mencari hutang sebagai sumber pendanaan utama maka akan semakin memperbesar biaya modal yang dikeluarkan

b. Profitabilitas menghasilkan tingkat signifikan 0,008 yang artinya tingkat signifikansi variabel profitabilitas dengan nilai $0,008<0,05$, maka dapat disimpulkan bahwa profitabilitas berpengaruh terhadap kebijakan hutang yang artinya $\mathrm{H}_{2}$ diterima. Kondisi ini menunjukkan bahwa perusahaan dengan tingkat profitabilitas tinggi akan cenderung menggunakan dana internal sehingga perusahaan tidak akan terlalu membutuhkan dana yang bersumber dari hutang, dengan demikian akan berdampak pada berkurangnya tingkat penggunaan hutang oleh perusahaan 
(Steven dan Lina, 2011).

Hasil penelitian ini sejalan dengan penelitian yang dilakukan oleh Sheisarvian et.al (2015), Susilawati et.al (2012), Steven dan Lina (2011), Karinaputri dan Sofian (2012). Hasil ini tidak sejalan dengan penelitian yang dilakukan oleh Astuti (2014) yang menyatakan bahwa semakin tinggi profitabilitas perusahaan maka nilai kebijakan hutang semakin tinggi. Kondisi tersebut kemungkinan disebabkan oleh semakin tinggi profitabilitas perusahaan, manajemen semakin yakin dengan kemampuannya untuk membayar hutang jangka panjangnya.

c. Kebijakan dividen menghasilkan tingkat signifikan 0,002 yang artinya tingkat signifikansi variabel kebijakan dividen dengan nilai $0,100>0,05$, maka dapat disimpulkan bahwa kebijakan dividen tidak berpengaruh terhadap kebijakan hutang yang artinya $\mathrm{H}_{3}$ ditolak. Menurut Kaaro (2001) dalam Karinaputri dan Sofian (2012) menyatakan bahwa kebijakan dividen sesungguhnya tidak relevan dengan kebijakan hutang. Kebijakan dividen akan lebih relevan dengan keputusan investasi daripada keputusan pendanaan.

Hasil penelitian ini tidak sejalan dengan hasil penelitian yang dilakukan oleh Sheisarvian et.al (2015) serta Steven dan Lina (2011). Hasil penelitian ini konsisten dengan hasil penelitian yang dilakukan oleh Djabid (2009), Susilawati et.al (2012) yang menyatakkan bahwa kebijakan dividen tidak berpengaruh terhadap kebijakan hutang hal ini menunjukkan bahwa kebijakan dividen belum menjadi informasi bagi perusahaan dalam menentukan kebijakan hutang oleh karena ada beberapa perusahaan yang tidak membagikan dividen.

d. Pertumbuhan perusahaan menghasilkan tingkat signifikan 0,002 yang artinya tingkat signifikansi variabel pertumbuhan perusahaan dengan nilai $0,002<0,05$, maka dapat disimpulkan bahwa pertumbuhan perusahaan berpengaruh terhadap kebijakan hutang yang artinya $\mathrm{H}_{4}$ diterima. . Secara teoritis adanya hubungan negatif antara pertumbuhan perusahaan terhadap kebijakan hutang dikarenakan perusahaan yang bertumbuh cenderung dapat menutupi beban-bebannya dari hasil operasional perusahaan sehingga tidak memerlukan pendandaan dari pihak ketiga.

Hasil penelitian ini mendukung penelitian yang dilakukan oleh Sanusi dan Nazar (2014) namun hasil penelitian ini tidak konsisten dengan penelitian yang dilakukan oleh Hendria (2015), Indahningrum dan Handayani (2009), yang menyatakan bahwa pertumbuhan perusahaan tidak berpengaruh terhadap kebijakan hutang.

e. Ukuran perusahaan menghasilkan tingkat signifikan 0,004 yang artinya tingkat signifikansi variabel ukuran perusahaan dengan nilai 0,004 
$<0,05$, maka dapat disimpulkan bahwa ukuran perusahaan berpengaruh terhadap kebijakan hutang yang artinya $\mathrm{H}_{5}$ diterima. . Hal ini mengindikasikan bahwa semakin besar perusahaan, maka akan memberikan kemudahan akses pencarian dana dari sumber eksternal atau hutang karena perusahaan mempunyai collateral assets yang semakin besar.(Astuti, 2014). Perusahaan besar akan lebih mudah untuk mengajukan pinjaman dibandingkan dengan perusahaan kecil.

Hasil penelitian ini konsisten dengan penelitian yang dilakukan oleh Hendria (2015), Syadeli (2013). Hasil penelitian ini tidak didukung oleh hasil penelitian yang dilakukan Narita (2012), Steven dan Lina (2011), Nuraina (2012) yang menyatkan ukuran perusahaan tidak berpengaruh terhadap kebijakan hutang karena perusahaan akan lebih memikirkan bagaimana memperoleh dana atau modal yang mempunyai browwing cost sekecil mungkin. Perusahaan besar maupun kecil pasti mempunyai hutang dan jumlahnya tidak selalu dipengaruhi oleh ukuran perusahaan tersebut.

\subsection{Koefisien Determinasi}

\section{Tabel 4.8}

Hasil Uji Koefisien Determinasi

\begin{tabular}{|l|c|r|r|c|}
\hline Model & $\mathrm{R}$ & $\mathrm{R}$ Square & $\begin{array}{c}\text { Adjusted } \mathrm{R} \\
\text { Square }\end{array}$ & $\begin{array}{c}\text { Std. Error of the } \\
\text { Estimate }\end{array}$ \\
\hline 1 &, $812^{\mathrm{a}}$ &, 660 &, 603 &, 2120653 \\
\hline
\end{tabular}

a. Predictors: (Constant), SIZE, STA, GROWTH, DPR, ROA

b. Dependent Variable: DER

Hasil uji Koefisien Determinasi yang tampak pada tabel di atas dapat diketahui bahwa nilai R, R Square, Adjusted R Square secara berurutan adalah 0,$812 ; 0,660 ; 0,603$. Nilai koefisien determinasi dihasilkan sebesar 0,7603 atau $60,3 \%$. Koefisien determinasi menunjukan bahwa kelima variabel independen yaitu struktur aset, profitabilitas, kebijakan dividen, pertumbuhan perusahaan dan ukuran perusahaan menjelaskan 60,3\% variasi yang terjadi pada kebijakan hutang. Sedangkan 30,7\% dijelaskan oleh variabel independen lain yang tidak dimasukan dalam penelitian ini.

\section{Kesimpulan dan Saran}

\subsection{Kesimpulan}

Berdasarkan analisis dan pembahasan yang telah dilakukan dalam penelitian ini dapat disimpulkan bahwa :

1. Struktur aset dengan nilai signifikansi sebesar 0,090 yang artinya lebih besar dari 0,05 sehingga struktur aset tidak berpengaruh terhadap kebijakan hutang. 
2. Profitabilitas dengan nilai signifikansi sebesar 0,004 yang artinya lebih kecil dari 0,05 sehingga profitabilitas berpengaruh terhadap kebijakan hutang.

3. Kebijakan dividen dengan nilai signifikansi sebesar 0,002 yang artinya lebih kecil dari 0,05 sehingga kebijakan dividen berpengaruh terhadap kebijakan hutang.

4. Pertumbuhan perusahaan dengan nilai signifikansi sebesar 0,000 yang artinya lebih kecil dari 0,05 sehingga pertumbuhan perusahaan berpengaruh terhadap kebijakan hutang.

5. Ukuran perusahaan dengan nilai signifikansi sebesar 0,074 yang artinya lebih kecil dari 0,05 sehingga ukuran perusahaan tidak berpengaruh terhadap kebijakan hutang.

\subsection{Saran}

Berdasarkan kesimpulan maka saran yang dapat penulis ajukan adalah sebagai berikut:

1. Bagi pengembangan ilmu, khususnya supaya analisis dilakukan lagi lebih mendalam dan lebih luas menggunakan faktor lain dengan mengganti variabel-variabel lain yang dimungkinkan berpengaruh terhadap kebijakan hutang.

2. Penelitian ini belum dapat membuktikan adanya pengaruh struktur aset, ukuran perusahaan terhadap kebijakan hutang. Penelitian ini hanya menggunakan perusahaan perbankan. Penelitian selanjutnya diharapkan menggunakan jenis perusahaan lain.

3. Bagi manajemen perusahaan meskipun dengan tingkat profitabilitas dan pertumbuhan perusahaan yang tinggi hendaknya tetap menjaga kestabilan hutangnya dan lebih berhati-hati dalam menentukan kebijakan hutang karena jika menggunakan hutang yang terlalu tinggi akan meningkatkan risiko keuangan perusahaan dan pada akhirnya bisa mengakibatkan perusahaan masuk ke dalam krisis (financial distress).

4. Bagi investor yang akan berinvestasi sebaiknya memperhatikan dan menganalisa faktor yang mempengaruhi kebijakan hutang perusahaan seperti tingkat profitabilitas (ROA), kebijakan dividen (DPR) dan tingkat pertumbuhan perusahaan karena secara tidak langsung kebijakan hutang mempengaruhi jumlah return yang diharapkan oleh investor.

5. Bagi para kreditur yang memberikan sumber pendanaan hutang supaya lebih memperhatikan aspek profitabilitas (ROA), kebijakan dividen (DPR) dan pertumbuhan perusahaan (Growth), karena perusahaan akan semakin membutuhkan pendanaan yang besar jika nilai ketiga variabel tersebut tinggi. 


\section{DAFTAR PUSTAKA}

Anam, Hairul. Rihfenti Ernayani \& Chyono Dwi. 2015. "Pengaruh Struktur Aset, Ukuran Perusahaan dan Pertumbuhan Perusahaan Terhadap Kebijakan Hutang”. Jurnal Sustainable Competitive Advantage (SCA), Vol. 5 No. 1. Desember 2015 hal 1-14.

Ariefianto, Doddy. 2019. Pertumbuhan Kredit Perbankan Melambat Jelang Pemilu 2019.Online.https://republika.co.id/berita/ekonomi/keuangan/powxio383/pertu mbuhan-kredit-perbankan-melambat-jelang-pemilu-2019. (25 Maret 2019).

Astuti, Elly. 2014. "Pengaruh Kepemilikan Institusional, Profitabilitas, Ukuran Perusahaan Terhadap Kebijakan Hutang Perusahaan". Jurnal Akuntansi dan Pajak, Vol. 15 No. 02. Januari 2014 hal :149-158.

Danarwati, Yanti Sri. "Perbankan Dalam Mengatasi Krisis Ekonomi Indonesia." Jurnal Mimbar Bumi Bengawan, Vol. 3 No.5 2010 hal : 1-15.

Dhani, Isabella dan Satia, Utama. 2017. "Pengaruh Pertumbuhan Perusahaan, Struktur Modal dan Profitabilitas Terhadap Nilai Perusahaan”. Jurnal Riset Akuntansi dan Bisnis Airlangga, Vol. 2. No. 1. 2017 hal : 135-148.

Djabid, Abdullah W. 2009. "Kebijakan Dividen dan Struktur Kepemilikan Terhadap Utang: Sebuah Perspektif Agency Theory”. Jurnal Keuangan dan Perbankan, Vol.13 No.2. Mei 2009 hal : 249-259.

Efni, Yulia. 2011. “Analisis Kebijakan Pendanaan, Kepemilikan Manajerial, dan Aliran Kas Bebas Terhadap Kebijakan Dividen" Pada Perusahaan Non Manufaktur Yang Terdaftar di BEI. Jurnal Ekonomi, Vol.19 No.01 2011 hal : $1-12$.

Financial Accounting Standards Board (FASB). 1985. "Statement of Financial Accounting Concept (SFAC) No.6 : Elements of Financial Statement.

Ghozalli, Imam. 2018. Aplikasi Analisis Multivariate dengan Program IBM SPSS 25. Edisi 9. Semarang : Badan Penerbit Universitas Diponegoro.

Harjito, D. Agus. 2006. "Hubungan Kebijakan Hutang, Insider ownership dan Kebijakan Dividen dalam Mekanisme Pengawasan Masalah Agensi di Indonesia”. Jurnal Akuntansi dan Auditing Indonesia, JAAI, Vol.10 No.2. Desember 2006 hal : 121-136.

Harjito, D. Agus. 2011. "Teori Pecking Order dan Trade-Off Dalam Analisis Struktur Modal di Bursa Efek Indonesia”. Jurnal Siasat Bisnis, Vol.15 No.2. Juli 2011 hal : 187-196.

Hendria, Reji. 2015. "Pengaruh Insider Ownership, Firm Size, Firm Growth, dan Business Risk Terhadap Kebijakan Hutang" (Pada perusahaan Perbankan Go Publik di Bursa Efek Indonesia). Jum FEKON, Vol.2 No.1. Februari 2015 hal : 1-15.

Hery. 2017. Kajian Riset Akuntansi. Jakarta : PT Grasindo. 
Hidayat, Syafiudin M. 2013. "Pengaruh Kepemilikan Manajerial, Kebijakan Dividen, Struktur Aktiva, Pertumbuhan Penjualan, Dan Ukuran Perusahaan Terhadap Kebijakan Hutang”. Jurnal Ilmu Manajemen, Vol.1 No.1. Januari 2013 hal : 12-25.

Ifadoh, Mely Nurul. 2015. "Pengaruh Risiko Bisnis, Pertumbuhan Perusahaan dan Struktur Aktiva Terhadap Kebijakan Hutang Pada Perusahaan Real Estate dan Propert yang Terdaftar di BEI Periode 2011-2014".Skripsi.Universitas Pancasakti Tegal.

Indahningrum, Rizki Putri dan Ratih Handayani. 2009. "Pengaruh Kepemilikan Manajerial, Kepemilikan Institusional, Dividen, Pertumbuhan Perusahaan, Free Chas Flow dan Profitabilitas Terhadap Kebijakan Hutang Perusahaan" Jurnal Bisnis dan Akuntansi, Vol.11. No.3. Desember 2009 hal : 189-207.

Junaidi, Darmawan. 2018. DPK Melambat Bank lirik Utang Bilateral.Online. https://keuangan.kontan.co.id/news/dpk-melambat-bank-lirik-utang bilateral. (10 Januari 2019).

Karinaputri, Nanda dan Sofian Syuhada. 2012. "Analisis Pengaruh Kepemilikan Institusional, Kebijakan Dividen, Profitabilitas dan Pertumbuhan Perusahaan Terhadap Kebijakan Hutang Studi Pada Perusahaan Manufaktur yang Terdaftar di Bursa Efek Indonesia Tahun 2008-2010”. Diponegoro Journal of Management, Vol.1 No.1 2012 hal :1-9.

Kasmir. 2014. Bank dan Lembaga Keuangan Lainnya. Edisi Revisi. Jakarta : PT RajaGrafindo Persada.

Made, Sudana. 2011. Manajemen Keuangan Perusahaan Teori \& Praktik. Surabaya : Erlangga.

Maryanti, Eny. 2016. “Analisis Profitabilitas, Pertumbuhan Perusahaan, Pertumbuhan Penjualan dan Struktur Aset Terhadap Struktur Modal Pada Perusahaan Sektor Industri Barang Konsumsi yang Terdaftar di BEI. (Studi Empiris Pada Perusahaan Manufaktur yang Terdaftar di Bursa Efek Indonesia Tahun 20122014)". Riset Akuntansi dan Keuangan Indonesia, Vol. 1 No. 2. 2016 hal : 143-151.

Mulyati, Yati. 2016."Pengaruh Struktur Asset dan Pertumbuhan Penjualan Terhadap Kebijakan Utang". UNEJ e-Proceending, 2016 hal :813-831.

Munawir, S. 2014. Analisis Laporan Keuangan Edisi Empat. Yogyakarta : Penerbit Liberty.

Musthafa. 2017. Manajemen Keuangan. Surabaya : ANDI Yogyakarta.

Mutamimah dan Rita. 2009. "Keputusan Pendanaan : Pendekatan Trade-Off Theory dan Pecking Order Theory". EKOBIS, Vol.10 No.1 Januari 2009 hal 241-249.

Nadillah, Dinda Yulmi. 2017. "Pengaruh Struktur Modal dan Pertumbuhan Perusahaan Terhadap Nilai Perusahaan yang Dimediasi Kinerja Keuangan 
dengan Pengungkapan Corporate Social Responsibility sebagai Variabel Pemoderasi Pada Perusahaan Manufaktur di BEI Tahun 2011-2014”. JUM Fekon, Vol.4 No.1 Februari 2017 hal : 601-615.

Narita, Rona M. 2012. “Analisis Kebijakan Hutang”. Accounting Analysis Journal, Vol.1 No.2. 2012 hal 1-6.

Noor, Fauzia Marwah. "Pengaruh Profitabilitas dan Ukuran Perusahaan Terhadap Nilai Perusahaan (Studi Kasus Pada Perusahaan Makanan dan Minuman yang Terdaftar di Bursa Efek Indonesia Periode Tahun 2010-2014

Nuraina, Elva. 2012. "Pengaruh Kepemilikan Institusional dan Ukuran Perusahaan Terhadap Kebijakan Hutang dan Nilai Perusahaan" (Studi pada Perusahaan Manufaktur yang Terdaftar Di BEI). JBE, Vol.19 No.2. September 2012 hal : 110-125.

Sartono, Agus R. 2001. Manajemen Keuagan Teori dan Aplikasi. Edisi Empat. Yogyakarta : BPFE-Yogyakarta

Sheisarvian, Revi Maretta, Nengah Sudjana \& Muhammad Saifi. 2015. "Pengaruh Kepemilikan Manajerial, Kebijakan Dividen, dan Profitabilitas Terhadap Kebijakan Hutang" (Studi pada Perusahaan Manufaktur yang Tercatat di BEI Periode 2010-2010). JAB, Vol.22 No.1 Mei 2015 hal : 1-9.

Sitanggang. 2013. Manajemen Keuangan Perusahaan Lanjutan. Jakarta : Mitra Wacana Media.

Steven dan Lina. 2011. "Faktor-Faktor yang Mempengaruhi Kebijakan Hutang Perusahaan Manufaktur". Jurnal Bisnis dan Akuntansi, Vol.13 No.3 Desember 2011 hal :163-181.

Subramanyam. 2017. Analisis Laporan Keuangan. Edisi 11- Buku 1. Jakarta : Salemba Empat.

Sudarsono, Heri. 2009. "Dampak Krisis Keuangan Global Terhadap Perbankan di Indonesia :Perbandingan antara Bank Konvensional dan Bank Syariah". Jurnal Ekonomi Islam, Vol.III No.1. Juli 2009 hal : 12-23.

Sujarweni, V. Wiratna, Marsudi Endang dan Lila Retnani. 2014. "Faktor-Faktor yang Mempengaruhi Kebijakan Hutang Studi Empiris Pada Perusahaan Manufaktur yang Terdaftar di BEI Tahun 2009-2012. JBTI, Vol. V No.1 Februari 2014 hal : 42-56

Susilawati, Christine Dwi Karya, Lidya Agustina, dan Se Tin. 2012. "Faktor-faktor Yang Memengaruhi Kebijakan Utang Perusahaan Manufaktur Yang Terdaftar Di Bursa Efek Indonesia”. Jurnal Keuangan dan Perbankan, Vol.16 No.2 Mei 2012 hal :178-187.

Syadeli, Moh. 2013. "Struktur Kepemilikan, Profitabilitas dan Ukuran Perusahaan terhadap Kebijakan Hutang Perusahaan Pemanufaktur di Bursa Efek Indonesia”. Jurnal Manajemen dan Akuntansi, Vol.2 No.2. Agustus 2013 hal : 79-94. 